\title{
KONSTRUKSI KEARIFAN LOKAL ISLAM ABOGE DI PROBOLINGGO
}

\author{
Haqqul Yaqin*
}

\begin{abstract}
Religion is a phenomenon associated with many dimensions, including the social dimension. Social thinkers such as Durkheim, Marx, and Weber also imply that religion is essentially more of a social aspect than a purely individual thing. Hence it can be said that there is an inevitable connection between religion as one of the social phenomena with many aspects of community life. Religion can also be said to be inseparable from the influence of the context of the society in which the religion develops. These influences can then be carried away in tradition and it is not uncommon to find that the content of religious interpretation has already contained a tendency of certain political interests.
\end{abstract}

Keywords: phenomenon associated, religious, tradition

\section{A. Pendahuluan}

Kedatangan Islam ke Indonesia merupakan salah satu proses yang sangat penting. Islam sudah ada di Indonesia selama berabad-abad sebelum Islam menjadi agama yang menyebar di kalangan masyarakatmasyarakat lokal. Menurut Ricklefs, ada dua proses yang mungkin terjadi dalam kontak antara Islam dan masyarakat lokal. Pertama, penduduk pribumi mengalami kontak dengan agama Islam dan kemudian mereka

* Dosen tetap Institut Ilmu Keislaman Zainul Hasan Genggong Kraksaan Probolinggo 
melakukan konversi. Kedua, orang-orang asing Asia (Arab, India, Cina) yang telah menganut agama Islam tinggal secara permanen di beberapa wilayah Indonesia, menikah dengan penduduk asli, kemudian berbaur sedemikian rupa dengan gaya hidup lokal sehingga mereka menjadi penduduk lokal. ${ }^{1}$

Agama merupakan suatu fenomena yang terkait dengan banyak dimensi, termasuk dimensi sosial. Para pemikir sosial seperti Durkheim, ${ }^{2}$ Marx, ${ }^{3}$ dan Weber ${ }^{4}$ pun menyiratkan bahwa agama secara esensial lebih merupakan sesuatu yang beraspek sosial daripada sesuatu yang murni individual. Karenanya dapat dikatakan bahwa ada kaitan yang tak terhindarkan antara agama sebagai salah satu fenomena sosial dengan banyak aspek kehidupan masyarakat. Agama juga dapat dikatakan tidak dapat lepas dari pengaruh-pengaruh konteks masyarakat di mana agama tersebut berkembang. Pengaruh-pengaruh tersebut lalu dapat terbawa dalam tradisi dan tidak jarang ditemukan bahwa isi interpretasi ajaran agama sudah mengandung tendensi kepentingan politik tertentu.

\section{B. Pembahasan}

\section{Sejarah Dinamika Islam di Probolinggo}

Sebelum Islam berkembang, Hindu dan Budha merupakan agama yang sudah mapan di Indonesia. Demikian pula dengan Probolinggo, sebelum masuk dan berkembangnya Islam di daerah ini, Hindu dan Budha merupakan agama yang telah masuk terlebih dahulu. Hal ini dapat dibuktikan dengan fakta sejarah bahwa Probolinggo merupakan wilayah yang berada di bawah kekuasaan Raja Majapahit yang ke-IV (1350-1389) yaitu Prabu Radjasanagara (Sri Hayam Wuruk). ${ }^{5}$ Majapahit merupakan

1 M. C. Ricklefs, Sejarab Indonesia Modern 1200-2008, terj. Tim Serambi, (Jakarta: Serambi, 2009), 3.

${ }^{2}$ Lih. Emile Durkheim, The Elementary Forms of The Religious Life, terj. Inyiak Ridwan Muzir \& M. Syukri (Yogyakarta: IRCISoD, 2011)

3 Lih. Daniel L. Pals, Seven Theories of Religion (New York: Oxford University Press, 1996)

${ }^{4}$ Lih. Max Weber, Sosiologi, terj. Noorkholish (Yogyakarta: Pustaka Pelajar, 2009)

5 Ibnu Said, dkk, Sejarab Singkat Kabupaten Probolinggo, (Probolinggo: Humas Pemkab Probolinggo, 1992), 3. 
kerajaan yang menganut agama Budha dan melakukan penyembahan kepada dewa-dewa Hindu, Siwa, dan Wisnu, serta terjadi penyatuan kedua agama itu pada diri sang raja, yang kemudian dianggap sebagai Siwa-Budha dan Nirguna bagi penganut Wisnu. ${ }^{6}$

Mapannya agama Hindu di Probolinggo dibuktikan dengan keberadaan candi (Jabung) yang konon dikatakan sebagai tempat persinggahan dan sesembahan raja-raja Majapahit ketika meninjau daerahdaerah kekuasaannya. ${ }^{7}$ Bahkan di desa Taman Sari terdapat sebuah kolam yang konon merupakan tempat peristirahatan dan pemandian raja dan punggawa kerajaan Majapahit. $^{8}$

Kehadiran Islam di Probolinggo telah merubah kehidupan masyarakat Probolinggo menjadi penganut Islam. Sebelum Islam datang, masyarakat Probolinggo berada dalam kehidupan percaya pada adanya kekuatan roh nenek moyang (animisme) dan percaya pada kekuatan yang terdapat pada benda-benda tertentu (dinamisme) serta adanya pengaruh Hindu-Budha. Hal ini dibuktikan dengan meresapnya nilai-nilai Islam dalam kehidupan sosial-budaya masyarakat Probolinggo. Sekalipun unsur-unsur ajaran pra-Islam belum terhapus, tetapi Islam telah mampu menjadi salah satu faktor pembentuk tradisi baru masyarakat setempat. Bahkan Probolinggo termasuk salah satu daerah penting yang menjadi basis penguatan Islam di Jawa Timur, yang dikenal dengan istilah Islam tapal kuda. ${ }^{?}$

\section{${ }^{6}$ M. C. Ricklefs, Sejarah Indonesia Modern, 35.}

7 Berdasarkan inskripsi yang terdapat pada pintu, candi Jabung didirikan pada tahun $1276 \mathrm{C}$ (tahun saka) atau bertepatan dengan tahun $1354 \mathrm{M}$, masa kebesaran kerajaan Majapahit. Dalam kitab Nagara Kertagama dan Pararaton, candi Jabung disebut dengan nama Bajrajinaparamitapura. Dalam kitab Nagara Kertagama, candi tersebut dikunjungi Hayam Wuruk pada tahun 1359.

${ }^{8}$ Lih. "Meski Mangkrak, Tetap Terjaga Pemandian Peninggalan Kerajaan Majapahit", Radar Bromo, 3 Pebruari 2013.

9 Tapal Kuda adalah nama sebuah kawasan yang terletak di bagian Timur propinsi Jawa Timur yang dalam Bahasa Inggris disebut The Eastern Salient. Dinamakan tapal kuda karena bentuk kawasan tersebut jika dilihat dalam peta mirip bentuk tapal kuda. Kawasan tapal kuda meliputi Pasuruan (bagian Timur), Probolinggo, Lumajang, Jember, Situbondo, Bondowoso, dan Banyuwangi. Pada masa Majapahit, kawasan tapal kuda merupakan wilayah bagian Majapahit Timur. Sedangkan pada masa Mataram, kawasan tapal kuda disebut Blambangan atau dalam budaya Jawa disebut daerah bang wetan (seberang Timur), karena kawasan ini tidak pernah menjadi bagian dari kerajaan Mataram. 
Kedatangan Islam ke Indonesia pasca Hindu-Budha, tidak sedikit berintegrasi dengan kepercayaan, tradisi, dan budaya lokal yang bernuansa Hindu-Budha. Islam dan budaya lokal saling bersinergi dan secara kreatif telah memperkaya mozaik peradaban Indonesia. ${ }^{10}$ Integrasi Islam dengan budaya lokal tidak lagi bersifat adaptatif melainkan mengarah pada perubahan yang akulturatif. Sebab di dalam elemen itu tidak sekedar terjadi proses saling meniru atau menyesuaikan satu dengan lainnya, akan tetapi mengakomodasi dua elemen menjadi satu kesatuan baru. ${ }^{11}$

\section{Lokalitas Aboge}

Sepintas pemunculan Islam Aboge di Probolinggo mencerminkan adanya proses akulturatif di atas. Pola kelompok dan corak generik yang dibangun menampilkan bangunan kharismatik yang baru dan sekaligus menciptakan pemisahan sektarian dari Islam mainstream yang ada di sana. Pada saat yang sama, Islam Aboge secara gradual banyak menggunakan arus besar praktisi-praktik kultural kelompoknya yang pada gilirannya diterima sebagai manifestasi agama yang mapan.

Aboge, demikian masyarakat Probolinggo biasa menyebutnya untuk satu keyakinan yang sudah secara turun temurun dianut oleh masyarakat Desa Kramat Agung, Desa Dringu, dan Desa Leces, Kabupaten Probolinggo. Islam Aboge merupakan model keyakinan dan cara keberagamaan yang memiliki sifat dan karakter yang berbeda dengan cara keberagamaan yang diyakini oleh kebanyakan masyarakat Probolinggo. Kata Aboge sendiri konon diambil dari sejarah lahirnya kelompok ini yang bertepatan dengan tahun alif, hari Rabu Wage. ${ }^{12}$

Secara geografis, Probolinggo berada pada daerah pesisir utara Pulau Jawa. Artinya bahwa masyarakat pesisir memiliki kekhasan kegiatan upacara-upacara yang bisa dibedakan dengan masyarakat pedalaman. Di antara yang paling dominan adalah sikap masyarakat pesisir yang lebih adaptif terhadap ajaran Islam dibanding dengan masyarakat

${ }^{10}$ Mark R Woodward, Islam Jawa: Kesaleban Normatif Versus Kebatinan, terj. Hairus Salim, (Yogyakarta: LKiS, 1999), 81.

${ }^{11}$ Lih. Gus Dur, Islam Pribumi. Juga lihat Nur Syam, Islam Pesisir, (Yogyakarta: LKiS, 2005), 242.

${ }^{12}$ Lih. Muhajirin Thohir, Wacana Masyarakat dan Kebudayaan Pesisir Jawa (Semarang: Bendera, 1999), 2 
pedalaman yang sinkretik. ${ }^{13}$ Sementara itu Islam Aboge Probolinggo lebih memperlihatkan sebagai - yang oleh Koentjaraningrat disebut disebut - agama Jawi.

Pemahaman polarisasi keberagamaan dengan menggunakan pendekatan dikotomistik santri-abangan Geertz akan kurang relevan manakala dibenturkan dengan kenyataan bahwa masyarakat (pedesaan) di Jawa lebih melihat agama sebagai sesuatu yang dinamis, yang berkembang dan berubah dari waktu ke waktu. Karena itu perkembangan Islam di Jawa tidak berjalan linear, tapi lebih ditentukan oleh kejutan historis dalam rentang perjalanan kehidupan masyarakat Jawa. ${ }^{14}$

Secara umum, terdapat dua pemahaman keislaman yang berbeda yang selama ini berkembang di Kab Probolinggo: Islam (yang menyatakan dirinya) ablus sunnah wal jammaah dan Islam Aboge. Islam ablus sunnab wal jamaah merupakan Islam mainstream yang dianut oleh kebanyakan masyarakat Probolinggo, atau praktik ajaran Islam resmi sebagaimana dipahami oleh mayoritas pemeluk Islam di Probolinggo. Tipe Islam yang pertama adalah tipe keberagamaan yang berorientasi pada ortodoksi ajaran. Organisasi keagamaannya mayoritas adalah Nahdlatul Ulama (NU). Sementara Islam Aboge merupakan tipe Islam yang dianggap menyimpang. Praktik keagamaan yang mereka lakukan dianggap mengandung unsur sinkretis, karena unsur-unsur adat dianggap lebih dominan di dalam memecahkan persoalan keagamaan daripada sumber utama agama Islam; al-Qur'an dan Hadits.

Sebutan Aboge muncul lebih dilatarbelakangi oleh praktik-praktik keagamaan yang selalu merujuk pada angka-angka dan warna magis yang disebut Petangan Jawi. Yaitu perhitungan baik-buruk yang dilukiskan dalam lambang dan watak suatu hari, tanggal, bulan, tahun, pranatamangsa, wuku, dan lain-lainnya. Petangan Jawi merupakan catatan leluhur berdasarkan pengalaman baik-buruk yang ditulis dan dihimpun dalam primbon yang dianggap sebagai jalan mencapai keselamatan dan kesejahteraan hidup lahir-batin. ${ }^{15}$

${ }^{13}$ Lih. Nur Syam, Islam Pesisir (Yogyakarta: LKiS, 2005), 165-166

${ }^{14}$ Lih. M. Bambang Pranowo, Memahami Islam Jawa (Tangerang: Pustaka Alvabet, 2009), 2-7

${ }^{15}$ Kata primbon berasal dari kata rimbu, berarti simpan atau simpanan. Maka primbon berarti memuat bermacam-macam catatan oleh suatu generasi dan secara 
Di tanah Jawa terdapat tiga model kalkulasi nasib dan cara menguji keberuntungan; lanang sejati tokohnya Yudhistira, kejawen tokohnya Pendowo Limo, dan Aboge tokohnya Ajisaka. Dengan demikian, model hitung-hitungan yang diadopsi oleh Islam Aboge Probolinggo adalah dari "madzhab" Ajisaka. Pola hitungan yang mereka miliki dilengkapi dengan rumus-rumus yang sudah dianggap paten, karena itu mereka sudah bisa menetapkan, misalnya, hari raya untuk jangka waktu puluhan tahun lamanya. Di sinilah sering terjadi konflik dengan kelompok Islam mayoritas ketika waktu lebaran/hari raya yang diadakan oleh Islam Aboge tidak sama. Biasanya mereka melaksanakan lebaran tiga hari setelah pengumuman resmi dari pemerintah atau yang umum dilaksanakan oleh umat Islam Indonesia.

Hal lain yang juga berbeda adalah pelaksanaan ibadah puasa yang tidak dilaksanakan pada bulan Ramadhan, tapi pada bulan lain sesuai dengan penghitungan ajisaka. Perbedaan penentuan bulan tentu akan berimplikasi pada penentuan pelaksanaan ibadah lainnya, misalnya pemberian zakat fitrah, perbedaan penentuan waktu pelaksanaan dua hari raya; idul fitri dan idul adha, juga pelaksanaan ibadah haji.

\section{Antroposentrisme Lokalitas Aboge: Sebuah Perspektif}

Pernyataan bahwa agama merupakan satu fenomena memberikan gambaran bahwa keberadaan agama tidak lepas dari pengaruh realitas di sekelilingnya. Seringkali praktik-praktik kehidupan pada satu masyarakat dikembangkan dari doktrin ajaran agama dan kemudian disesuaikan dengan lingkungan budaya. Pertemuan antara doktrin agama dan realitas budaya terlihat sangat jelas dalam praktik ritual agama. ${ }^{16}$ Dan pembauran Islam dengan budaya lokal kemudian menghasilkan varian Islam yang khas dan unik. Selanjutnya proses tersebut melahirkan pola hubungan dan praktisi keagamaan yang didasarkan pada kepercayaan terhadap para leluhur. Komunitas ini dianggap sebagai bagian dari Islam Kejawen, yang dalam istilah Geertz disebut Islam Abangan. ${ }^{17}$

terus menerus diturunkan dari satu generasi ke generasi. Lih. M Hariwijaya, Islam Kejawen (Yogyakarta: Gelombang Pasang, 2006), 245.

${ }^{16}$ T. William Hall (ed.), Introduction to the Study of Religion, (New York: Harper \& Row, 1978), 64-66

${ }^{17}$ Abdurrahman M, "Islam Aboge: Harmoni Islam dan Tradisi Jawa", dalam 
Pertautan antara agama dan realitas budaya dimungkinkan terjadi karena agama tidak berada dalam realitas yang vacum-selalu original. Mengingkari keterpautan agama dengan realitas budaya berarti mengingkari realitas agama sendiri yang selalu berhubungan dengan manusia, yang pasti dilingkari budayanya. Kenyataan yang demikian memberikan arti bahwa perkembangan agama dalam sebuah masyarakat - baik dalam wacana maupun praktik sosialnya - menunjukkan adanya unsur konstruksi manusia (empiris-sosiologis). Walaupun tentu pernyataan ini tidak berarti bahwa agama semata-mata ciptaan manusia, hubungan yang tidak bisa dielakkan antara Konstruksi Ilahiyah - seperti yang tercermin dalam kitab-kitab suci - dan konstruksi manusia; interpretasi dari nilai-nilai suci agama yang tercermin dalam praktek ritual keagamaan. ${ }^{18}$

Agama, dengan demikian, menampilkan dua sisi tersebut: yaitu sisi antroposentris dan sisi teosentris. Sisi teosentris memandang Tuhan di atas segalanya, kedudukan manusia adalah dalam rangka ketundukan itu sendiri tanpa harus dimengerti sebagai prosesi imanensi. Sementara term antroposentris dipahami bahwa kemanfaatan agama selalu pada ukuran-ukuran kemanusiaan. Sisi kemanusiaan sebagai dasar segala aktivitas, sehingga spiritual maupun ritus akan selalu disandarkan dalam konteks kemanusiaan. Kehadiran sisi humanitarian ini dapat dilihat pada aktualisasi interaksi sosial.

Sisi humanitarian fenomena agama tersebut dalam perkembangannya kemudian melahirkan konstruksi sosial. ${ }^{19}$ Yaitu suatu kondisi sosiologis yang oleh Berger dan Luckmann dianggap sebagai hasil ciptaan manusia kreatif melalui kekuataan konstruksi sosial terhadap dunai sosial di sekelilingnya. Proses konstruksi berlangsung melalui interaksi sosial yang

kumpulan makalah pada The $11^{\text {th }}$ Annual Conference on Islamic Studies, Bangka Belitung,11-13 Oktober 2011.

${ }^{18}$ Lih. Michael S. Northcott, "Sosiological Approaches" dalam Peter Connolly (ed), Approaches to The Study of Religion (New York: Cassell, 1999)

${ }^{19}$ Teori konstruksi sosial yang dicetuskan oleh Berger \& Luckmann ini banyak dipengaruhi oleh pemikiran sosiologi yang lain. Terutama terpengaruh oleh ajaran dan pemikiran Schutzian tentang fenomenologi, Weberian tentang makna subjektif (melalui Carl Meyer), Durkhemian-Parsonian tentang "struktur" (melalui Albert Solomon), dan Marxian tentang "dialektika", serta Herbert Mead tentang "interaksi simbolik". 
dialektis dari tiga bentuk realitas yang menjadi entry concept, yakni subjective reality, symbolic reality dan objective reality. Ketiganya berlangsung dalam suatu proses dengan tiga momen simultan; eksternalisasi, objektivikasi dan internalisasi. ${ }^{20}$

Upaya memahami konstruksi komunitas Aboge harus diawali dengan terlebih dahulu mendefinisikan makna "kenyataan" dan "pengetahuan". Kenyataan sosial komunitas adalah hal implisit dalam pergaulan sosial yang dapat diungkapan melalui komunikasi bahasa, hubungan antar organisasi sosial, atau melalui ekspresi budaya lainnya. Karena itu kenyataan sosial tersebut dapat ditemukan dalam pengalaman intersubjektif yang terbentuk secara simultan (unlimited). Konsep intersubyektifitas menunjuk pada dimensi struktur kesadaran umum komunitas ke kesadaran individual anggota dalam suatu kelompok khusus yang saling berintegrasi dan berinteraksi. ${ }^{21}$ Dengan demikian, kenyataan merupakan entitas dengan kualitas yang diakui sebagai memiliki keberadaan (being) yang tidak bergantung kepada kehendak kita sendiri.

Sedangkan pengetahuan mengenai realitas komunitas Aboge terarah pada bentuk-bentuk penghayatan kehidupan sosialnya secara menyeluruh baik secara kognitif, psikomotoris, emosional dan intuitif. Dengan kata lain, kenyataan sosial komunitas Aboge tersirat dalam pergaulan sosial, yang diungkapkan secara sosial dan termanifestasikan dalam tindakan. Kenyataan sosial semacam ini ditemukan dalam pengalaman intersubyektif (intersubjektivitas). Melalui intersubyektifitas dapat dijelaskan bagaimana kehidupan komunitas Aboge dibentuk secara terus-menerus.

Dalam konteks di atas, dapat dijelaskan bahwa perbedaan penekanan penafsiran terhadap ajaran-ajaran agama (Islam) berekses pada munculnya varian manifestasi kehidupan keagamaan yang berkembang di kalangan masyarakat Jawa. Masyarakat tidak bersikap pasif dalam menerima dan memahami ajaran agama Islam, serta dalam melestarikan dan mengembangkan tradisi Islam. Intersubjektivitas pemahaman elit Aboge dengan teks normatif Islam melahirkan fenomena beragama tersebut.

Sebagai kenyataan objektif, komunitas Aboge merupakan suatu

${ }^{20}$ Peter L. Berger, Langit Suci: Agama Sebagai Realitas Sosial, terj. Hartono, Jakarta: LP3ES, 1994, 4-5

${ }^{21}$ Peter L. Berger \& Thomas Luckmann, The Social Construction of Reality: A Treatise of Sociology of Knowledge, New York: Penguin Books, 1966, 35-41. 
faktisitas yang berada di luar individu anggotanya. Komunitas Aboge merupakan kenyataan empiris yang mewujud dalam individu anggota melalui proses interaksi sosial dalam dunia intersubjektif yang terlembagakan (society is an objective reality). Sementara sebagai kenyataan subjektif, individu sebagai anggota komunitas merupakan sesuatu yang tidak terpisahkan dari komunitas Aboge (man is a social product). Dengan demikian, kenyataan sosial tidak bisa dipahami dalam karakternya yang tunggal, tapi harus ganda: objektif dan subjektif. Objektif artinya bahwa kenyataan berada di luar masyarakat, dan subjektif bahwa kenyataan berada dalam diri masyarakat ${ }^{22}$.

Bagaimana menyambungkan yang objektif dan subjektif di atas, maka Berger kemudian menerapkan konsep dialektika di dalam kerangka tesis, antitesis, dan sintesis. Ketiganya bergerak dalam tiga moment secara simultan yang kemudian diistilahkan dengan eksternalisasi, yaitu pencurahan individu anggota ke dalam dunia sosial Aboge secara terus menerus, baik fisis maupun mental; objektifasi, yaitu proses interaksi sosial intersubfjektif yang berupa tipifikasi dan faktisitas yang mandiri; internalisasi, penyerapan kembali realitas sosial Aboge ke dalam individu dan mentranformasikannya ke dalam struktur-struktur kesadaran subjektif. ${ }^{23}$

Interplay dialektis di atas melahirkan realitas sebagai hasil ciptaan manusia kreatif melalui kekuataan konstruksi sosial terhadap dunia sosial di sekelilingnya. Selanjutnya realitas tersebut "dilembagakan" melalui suatu proses pembiasaan (habitualisasi), yaitu tindakan yang dilakukan secara berulang-ulang sehingga membentuk pola-pola tertentu dan direproduksi sebagai pola yang dipahami bersama. Proses pembiasaan mendahului setiap pelembagaan, karena pelembagaan bisa terjadi bila ada suatu tipifikasi timbal-balik dari tindakan-tindakan yang sudah terbiasa dari berbagai tipe pelaku.

Menurut Berger, pelembagaan terjadi apabila terdapat tipifikasi timbal-balik dari tindakan-tindakan yang habitualized. Artinya bahwa setiap tipifikasi - bisa bisa berupa ritus dan upara keagamaan - merupakan suatu lembaga selama tetap mengandaikan adanya hubungan timbalbalik (reciprocity). Tipifikasi tindakan beragama yang sudah dijadikan

\footnotetext{
${ }^{22}$ Ibid, 71-80.

${ }^{23}$ Peter L. Berger, Langit Suci, 4-5.
} 
kebiasaan akan selalu menjadi milik bersama dan terbuka bagi semua anggota kelompok sosialnya. Karena itu, komunitas Aboge tersebut pada gilirannya akan mentifikasi setiap pelaku, sekaligus tindakannya. Komunitas tersebut akan mengarahkan bahwa tindakan-tindakan yang spesifik akan dilakukan oleh pelaku-pelaku yang spesifik.

Pada perkembangannya, institusionalisasi Aboge memerlukan legitimasi. Yaitu cara yang dapat membenarkan dan dapat menjelaskan proses pelembagaan tersebut. Sebagai proses, pelembagaan digambarkan sebagai suatu objektifikasi makna pada level kedua. Secara fungsional, legitimasi akan membuat objektifikasi level pertama yang sudah dilembagakan menjadi tersedia secara objektif dan masuk akal secara subjektif. Dengan demikian, legitimasi mengandung unsur kognitif sekaligus normatif, legitimasi tidak sebatas masalah nilai-nilai tapi juga mengimplikasikan pengetahuan. ${ }^{24}$

Namun begitu, semua dunia yang dibangun secara sosial adalah rawan, karena keberadaannya terancam oleh kepentingan diri manusia atau kebodohan manusia. Karena itu, diperlukan legitimasi untuk pemeliharaan eksistensinya, salah satunya adalah agama. Agama secara historis merupakan instrumen legitimasi yang paling masif dan efektif. Semua legitimasi mempertahankan realitas yang didefinisikan secara sosial. Agama membangun legitimasi sangat efektif karena mampu menghubungkan konstruksi realitas yang rentan dengan realitas purna. Realitas rentan dunia sosial itu didasarkan pada realitas keramat yang menurut definisinya berada di luar kemungkinan-kemungkinan yang timbul dari makna-makna manusiawi dan aktivitas-aktivitas manusia. ${ }^{25}$

Agama melegitimasi lembaga-lembaga sosial dengan memberikannya status ontologis yang absah, yaitu dengan meletakkan lembaga-lembaga di dalam suatu kerangka acuan keramat dan kosmik. Konstruksi-konstruksi historis aktivitas manusia dilihat dari suatu titik tinggi yang mengatasi (transcend) sejarah ataupun manusia. Sesuatu yang transenden melegitimasi apa yang ada di bawahnya. Bentuk legitimasi yang paling kuno adalah tatanan kelembagaan yang langsung mencerminkan atau mewujudkan struktur ilahi, yaitu konsepsi hubungan antara masyarakat dan kosmos sebagai hubungan antara mikrokosmos dan makrokosmos. Segala yang

\footnotetext{
${ }^{24}$ Ibid, 110-111.

${ }^{25}$ Peter L. Berger, Langit Suci, 40.
} 
"di bawah sini" memiliki analog dengan yang "di atas sana". Dengan berpartisipasi dalam tatanan kelembagaan maka manusia berpartisipasi dalam kosmos ilahiah. ${ }^{26}$

Agama yang secara historis penting dalam proses legitimasi, semakin jelas lagi kalau disadari perihal kemampuan unik dirinya "menempatkan" fenomena-fenomena manusia di dalam suatu acuan kosmik. Semua legitimasi bertindak memelihara realitas sebagai suatu kolektivitas manusia tertentu. Legitimasi religius (yang diberi agama) menghubungkan realitas yang didefinisikan secara manusiawi dengan realitas purna yang universal dan keramat. Di sini konstruksi-konstruksi aktivitas manusia yang rawan dan bersifat sementara mendapatkan kemantapan dan ketetapan purna. ${ }^{27}$

\section{Penutup}

Kehidupan keagamaan sebagai proses yang dinamis bukan kondisi yang statis. Setiap individu dianggap sedang berada dalam proses "menjadi" (becoming) dan bukannya "mengada" (being). Proses "menjadi" ini tidak hanya diarahkan pada level individu, melainkan juga pada tingkatan sosial. Proses sosial yang menjadi landasan di sini adalah proses yang ditandai oleh semakin meluas dan berkembangnya pengaruh Islam yang lebih ortodoks tanpa harus menggusur warisan kultural yang telah ada di tengah kehidupan masyarakat.

Menyadari betapa kompleks dan majemuknya komunitas Islam Jawa, maka fakta Muslim Jawa harus diperlakukan sebagai Muslim yang sebenarnya, tanpa memandang kaku derajat kesalehan dan ketaatan mereka. Perbedaan manifestasi religiusitas seorang Muslim harus dianalisis berdasarkan perbedaan penekanan dan penafsiran atas ajaran-ajaran Islam, tidak atas dasar keimanan dan ibadah Muslim Indonesia dibandingkan dengan ras-ras Muslim lain.

Allahu a'lam bi al-shawab.

\footnotetext{
${ }^{26}$ Peter L. Berger, Langit Suci, 41.

${ }^{27}$ Ibid, 44.
} 


\section{Daftar Pustaka}

Berger, Peter L, Langit Suci: Agama Sebagai Realitas Sosial, terj. Hartono, Jakarta: LP3ES, 1991

, Sosiologi Ditafsirkan Kembali, Esei tentang Metode dan Bidang Kerja, terj. Herry Joediono, Jakarta: LP3ES, 1985

, Pikiran Kembara, Modernisasi dan Kesadaran Manusia, terj.

A. Widyamartaya, Yogyakarta: Kanisius, 1992

, dan Thomas Luckmann, The Social Construction of Reality, $A$ Treatise in The Sociology of Knowledge, England: Penguins Book, 1967

Capps, Walter H., Religious Studies, The Making of a Discipline, Minneapolis: Fortress Press, 1995

Connolly, Peter, ed., Approaches to the Study of Religion, New York: Cassell, 1999

Durkheim, Emile, The Elementary Forms of The Religious Life, Sejarab Bentukbentuk Agama yang Paling Dasar, terj. Inyiak Ridwan Muzir \& M. Syukri, Yogyakarta: IRCiSoD, 2011

Fluehr-Lobban, Carolyn, Islamic Societies in Practice, Florida: University Press of Florida, 2004

Geertz, Clifford, Abangan, Santri, Priyayi dalam Masyarakat Jawa, terj. Aswab Mahasin, Jakarta: Pustaka Jaya, 1965

Hariwijaya, M., Islam Kejawen, Yogyakarta: Gelombang Pasang, 2006

Jones, Pip, Pengantar Teori-teori Sosial dari Teori Fungsionalisme hingga Postmodernisme, terj. Achmad Fedyani Saifuddin, Jakarta: YOI, 2009

Koentjaraningrat, Metode Antropologi dalam Penyelidikan Masyarakat dan Kebudayaan di Indonesia, Djakarta: Penerbitan Universitas, 1958

Kuntowijoyo, Islam Sebagai Ilmu: Epistemologi, Metodologi, dan Etika, Yogyakarta: Tiara Wacana, 2007

Martin, Richard C. ed., Approaches to Islam in Religious Studies, The University of Arizona Press, USA 
Pals, Daniel L., Seven Theories of Religion, New York: Oxford University Press, 1996

Pranowo, M. Bambang, Memahami Islam Jawa, Tangerang: Pustaka Alvabet \& INSEP, 2009 , Islam Faktual: Antara Tradisi dan Relasi Kuasa, Yogyakarta: Adicita Karya Nusa, 1999

Ricklefs, M. C., Sejarah Indonesia Modern, terj. Tim Serambi, Jakarta: Serambi Ilmu Semesta, 2009 , Mengislamkan Jawa, terj. FX Dono Sunardi \& Satrio Wahono, Jakarta: Serambi Ilmu Semesta, 2013

Ritzer, George \& Douglas J. Goodman, Teori Sosiologi Modern, terj. Alimandan, Jakarta: Prenada Media, 2005

Spradley, James P., Metode Etnografi, terj.Misbah Zulfa Elizabeth, Yogyakarta: Tiara Wacana, 1997

Tjandrasasmita, Uka, Arkeologi Islam Nusantara, Jakarta: KPG, 2009

Turner, Bryan S., Relasi Agama dan Teori Sosial Kontemporer, terj. Inyiak Ridwan Muzir, Yogyakarta: IRCiSoD, 2012

Weber, Max, Sosiologi, terj. Noorkholish, dkk., Yogyakarta: Pustaka Pelajar, 2009

Woodward, Mark R., Islam Jawa: Kesalehan Normatifversus Kebatinan, terj. Hairus Salim HS., Yogyakarta: LKiS, 1999 